\title{
I. Observations on living animals found inclosed in stones and other solid substances
}

\section{F.W.A. Murhard}

To cite this article: F.W.A. Murhard (1799) I. Observations on living animals found inclosed in stones and other solid substances, Philosophical Magazine Series 1, 3:11, 225-233, DOI: 10.1080/14786449908676987

To link to this article: http://dx.doi.org/10.1080/14786449908676987

曲 Published online: 18 May 2009.

Submit your article to this journal $\lceil\pi$

Џll Article views: 2

Q View related articles $\square$ 
THE

\section{PHILOS OPHICAL MAGAZINE.}

APRIL 1799 .

I. Obfervations on Living Animals found inclofed in Stones and otber folid Subftances. By F. W. A. MurHA rD. From Magazin für das neuefte aus der Phyfik. Vol. XI.

F living animals being found inclofed in folid maffes, $I$ have met with no mention in the works of the ancients. Martial, indeed, in one of his epigrams, fpeaks of infects inclofed in amber ; but thefe animals were dead, and therefore do not belong to this fubject. As far as I know, Fulgos * is the firft author who makes mention of a living toad being found inclofed in a ftone. He wrote about the beginning of the fixteenth century; and the circumftance took place in the village of Meudon in Italy, in the time of Pope Martin V. He was informed by a ftone-cutter that there was nothing furprifing in it, as fuch phenomena had often occurred to himfelf. Agricola, who lived afterwards, fpeaks of poifonous frogs being found in Ptones, but which foon died when expofed for a fhort while to the air. Aldrovandi $\uparrow$ alfo fpeaks of marble in which thefe animals were found

* See his work De Mirabilibus. Mediol. I509, fol, and Antverp. 1565.8, in the chapter $D e$ avibus animalibufque aliis admirandis.

+ Aldrovandi De Tefaceis, p. $8 \mathrm{r}$.

VOI, III,

alive. 
alive. Ray* at firft doubted the truth of thefe relations; but his doubts were foon removed by the undubitable teftimony of eye-witneffes. Accounts of a fimilar kind may be found in Francifci's Theatre of Various Curio/ities, printed at Nuremberg in $167 \mathrm{I}+$. The author there fpeaks of toads, crabs, ferpents and fhell-fin found in flones; but it is very evident that he confounds thefe with petrifactions.

Lloyd, in the third letter at the end of his Litbopbylaciz Britannici Icbnograpbia $\$$, fays, he was informed by Dr. Kichardfon that he had found a living toad inclofed in a folid rack. Dr. Bradley $\S$ mentions a fact of the like kind, having been witnefs to a toad being found in the trunk of a large oak. We are told in the Hiftory of the Academy of Sciences of Paris for the year 1719, that a toad was found inclofed in an elm as thick as a man's body. As foon as the trunk was cleft the animal dropped out, and no opening could be difcovered through which it had got in to the heart of the wood. A fimilar circumftance is mentioned in the fame work for $173 \mathrm{I}$, viz. of a toad being found in ar oak at leaft eighty or a hundred years old $\|$.

Labat, in his Travels through Spain and Italy 4 , gives a very minute defcription of a kind of fhell-fith found in ftones fifhed up from the fea in the territories of Civita Vecchia, and which were eaten by the inhabitants. "While walking," fays he, "on the coaft of Biclitere, I had the pleafure of feeing fithed up feveral fea dates (dattoli di mare) which are produced and grow in certain ftones of a fome-

* Synopfis Animal. Quadruped. p. zx.

+ Der luftigen Schan-Binhe vielerband Curiefitaten ater Theile durch Erafmum Francifci. Nurembcrg, 1671 8. p. 1109.

† Lond. 1608.8, p. 107.

$\S$ A Philofophical Account of the Works of Nature. Lond. I ? 21. 4to. p. 9 and 120. See alfo ACla emditorum. Lip. 1721. p. 370.

II See alfo A\&ta eruditorum. Lip. Suppl. VIII.

T) Voyages en Efpagne et en Italie. Amt. $\times 73$ 1.8. vol, iv. p. 240.

what 
what pongy nature, found in great abundance in the Adriatic Sea, and of which there are fome alfo in the port of Civita Vecchia. Thefe fea dates; which are a kind of mufcles, are almoft round, pointed at both ends, and confift of two fhells which open on one fide, and are from one or two to nearly four inches in length. The thell is of the fame quality as that of the common mufcle, but it is a little browner and lefs fmooth on the outfide. The infide has a fomewhat filvery appearance. The fifh which they contain is white, delicate, fat, and of a very agreeable tafte, fo that it is a morfel for a cardinal (un boccone di cardinale). They are called dates, becaufe the thell which contains the fifh has a great refemblance to the dates of Barbary when they are ripe and dried. The ftone in which they are inclofed is heary and pretty folid, though it appears fpongy. The cavity which the fhell occupies in the ftone, and which it exactly fills, touches it on all fides like the beft fitted cafe. Some fmall ones are not half an inch in length, but others are four inches. When the fifhermen had procured a fufficient number of the ftones, they placed them on the edge of the quay, and broke them by means of a large hammer. In fome they found nothing, but others contained two or three dates. They gave fome of them to me, together with fragments of the ftone which inclofed them, and on which I made the above obfervations."

Inftances of a fimilar kind may be found alfo in various other works. Thus we are told that Charles Hall, a merchant at Eberach, faw a living toad fitting in a ftone, upon its being broken. Martin Weinreich * relates a circumftance of the like kind; and John Nardius + fays, that he found in a block of marble a living fnake. Libavius fpeaks of vipers and toads found in ftones, as does alfo Cardan. A living

* Commentar. de Monfris, cap. vii. p. $5^{8}$.

$\uparrow$ Juan. Nard. in Ann. x. noct. gen. 4. p. 266.

Q 2 
toad was found in an oak by Seigne in 1731 , and another in a hard ftone, at Ecretteville, by Le Prince in $175^{\circ}$.

A great many particulars relating to this fubject have been collected by Guettard. A common toad, two of whofe feet were free, and the other two fticking faft in gypium, fo that it was impolfible to difengage them without tearing them to pieces, was fent to him by order of the Duke of Orleans. Count Hermann II. of Hatzfeld, told Dr. Sachfen + that he heard a living frog croak in the middle of a ftone at his palace of Schellenberg, near Cologne, and that the animal hopped out on the ftone burfting of itfelf. I fhall now give a few other inftances, of which Guettard makes no mention.

In the year 1733 a living toad was found by J. M. Gräberg in a folid hard block of ftone, dug up from a quarry in the parifh of Wamblingebo, in Gothland, and which he caufed to be broken by the workmen. The colour of the animal was blackifh grey, a little fpotted on the back, and fomewhat fainter on the belly. Its eyes were fmall and round, and covered by a tender kkin or film, under which they feemed to fparkle a little with a colour like that of pale gold. Having touched it on the head with a ftick, it contracted" its eyes as. if it had been alleep: as foor as the fick was removed, it gralually opened them; but moved neither its body nor feet in the leaft, though he touched it different times. He remarled alfo that the mouth had no aperture. It was covered with a yellowifh fkin, which he examined alfo with the ftick, but he was not able to make it

* Inftances of the like kind may be found in the followinfworks: Haller de corp.bum. fabr. et funt. vol. vii. p. 157; Aqant Coureur, 15 Sept. 7 66; Cbr. Franc. Paulleni in Bufone, c. 3. Jed.i. p. 33 ; Cbrif. Er. Garmann in Oolog. curr. difs. 1i. p. 145. \$120; Nierenberg. Hift. Nat. lib. vi. e. 13 ; D. Baufcbius de Aetite, F. 74 ; Eufeb. Cbrij. Fronkens Hiftorie der Crafscbaft Monnsfeid, Leip. 1723 . vol. i. ch. 5 ; Leffrs Litbotbeologie, Hamburgh 175 1.8. F. 101 and i12.

+ Memorres fur differens parties des Sciences et des Arta. Paris $1783 \cdot 4$. vol. iv. p. $615 \sigma$ 
open it. Having at laft preffed it on the back, a little clear water iffued from it behind, upon which it immediately died*. Don Antonio de Ulloa, who with Condamine, Bouguer and Godin, was employed in meafuring a degree of the meridian in Peru, faw at Madrid two worms which had been found in the middle of a block of marble by the king of Spain's ftatuary. Miffón, in his Travels through Italy, fpeaks of a living crab found in a piece of marble near Tivoli. M. Peyfonnel, phyfician to the king of France, having employed fome workmen to dig a well near his houfe in Guadaloupe, they found living frogs amidit the ftrata of the rock. His curiofity being excited by this circumftance, he defcended into the well himfelf, bored into the rock, and brought up alive fome green frogs, which had a perfect refemblance to the common ones.

In the Gentleman's Magazine for 1756 mention is made of a living toad found in a block of marble, at an old caftle belonging to Lord Tankerville, twelve miles north-weft from Alnwick + . T. Whifton relates, that in the year 1743 a ftone-cutter named Charlton found near Wibich, in the Ine of Ely, a living toad inclofed in a piece of marble $f$. Being called to the fpot, he faw the animal, and the cavity in which it was contained. The latter was fomewhat larger than the toad, and had almoft the fame figure. The animal was of a dark yellow colour; and the folid marble, which inclofed it on all fides, was feveral inches thick. It feemed to be quite healthy, and by its long confinement had not become meagre. John Malpas allo, in the year 1755, found a living toad inclofed in a piece of free-ftone at Great Yarmouth $\S$. The hole in which it lay was fix inches diftant from the corner of the ftone. He took it out with a pair of

$\because \dot{r}$ Kongl. Swenka Vetenkaps Academiens, handlingar for ar 374 r. p. 248.

† Gentleman's Magazine, 1756, p. 74 .

$\$$ Lbir. May 1756, p. 240 .

§ See Gentleman's Magazine, loc. cit. 
compaffes, but in doing fo happened to hurt it. When he placed it on the ground it however crept about, but died in the courfe of an hour. It had a yellow ftripe over the back, the colour of which became changed after it was dead. No crack or cleft could be difcovered in the ftone. The infide of the cavity was fmooth, and looked as if it had been polifhed.

M. Gerhard, at Padenburg, in the county of Mansfeld, faw likewife a living toad inclofed in a ftone. The cavity in which it lay feemed exactly fitted to the fize of the animal, but was exceedingly fmooth in the infide. No opening could be obferved through which it was poffible for it to have got into the ftone. After fome fearch, however, a hole was difcovered at the furface of the earth, which extended to the depth of twelve toifes; but ceafed at the diftance of thirteen inches above the cavity that contained the toad. M. Gerhard confiders it as very probable that this aperture had formerly extended to the cavity, into which the egg of a. toad might have been conveyed by water; and that the opening muft afterwards have been clofed up near the cavity. The toad, however, muft have remained long in this ftate; for fuch apertures do not clofe up foon; and a long time is required for the petrifaction of earthy particles *.

M. le Cat $\uparrow$, who relates many inftances of the like kind, examines the polfibility of them, and the caufes of fuch phenomena. Some philofophers have been of opinion, that the eggs of thefe animals, created by the Supreme Being at the beginning of the world, and floating about on the watery expanfe, have fince that time been inclofed in the interior parts of the rocks. But M. le Cat contradicts this opinion by rcmarking that the creation of an egg is not fufficient, and that it nuft be hatched in order to produce a living: creature. He confiders it alfo as impoffible that fuch ani-

- See Nouveaux Memoires de l'Acad. des Sciences et Belles Lettres de Pruffc pour lannée $x_{782}$. Berlin $1_{7} S_{4}, 4$ to. p. $x_{3}$.

t In Du Lac Melanges d'Hhoire Naturelle, vol. iv. p. 6 is. 
mals.can be of the fame antiquity as the ftones or fubfances in which they are found. The age of the oldef men, fays he, never exceeded 169 years; and what is the life of an infect when compared with that of man? Even if we fuppofe that the moderation of thefe animals, and their being expofed to very little motion, had caufed their growth and the periods of their life to be extended in an uncommon degree; and though their want of air, or rather their being preferved and defended from the manifold impreffions of that corrupted element, had contributed a great deal to their fupport, the prolongation of life thence arifing could not exceed fo very much their natural and ufual exiftence. $M$. le Cat rather thinks that a hatched egg, in all the cafes mentioned, may have fallen by chance into fome fmall cavity, where it was fecured from petrifaction till its fubftance acquired fufficient ftrength. He here remarks that eggs, when rubbed over with varnith fo as to be defended from the effects of the air, may be preferved fruitful for years; and he therefore believes, on good grounds, that an egtg fo fecured in the centre of a rock might retain its activity for fome thoufands of years, and even that it would be impoffible for it to be hatched till it had been expofed to a very high degree of often renewed or long continued heat. According to M. le Cat's opinion it is the egrowich is of great aniquity, and not the animal. I thall here obferve that nature, when allowed peace and reft, does not require fo. much time as is generally believed in order to produce minerals. Of the truth of this remak I am fully convinced, fince I faw in the mufeum at Gottingen the ftep of a ladder found on clearing the gallery of a mine in Ramndtberg, abandoned at moft about 100 years before, and which in the courfe of that period had been encrufted with felenite feven inches in thicknefs. Nay we have inftances of ore having grown up in a much fhorter time*.

* See Ulloas Nacbricbe von Anerica, vol. ii. p. 14, and Tiebras Erfaljrungen von Innern der Geburge, p. 53, tab. 4, no. 4 . 
I muft obferve alfo, that moft of the animals found in this manner were of the amphibious kind, and requeft the reader to reflect on the habits, nature and mode of living peculiar to that clafs. Caldefi relates, that tortoifes can endure hunger for half a year; and numberlefs inftances might be produced of their ftrong and tough nature.

I hall not enlarge farther on this fubject at prefent, as I mean at fome future period to communicate my ideas to the public in a more connected manner, and to give as complete a theory on it as poffible. I flatter myfelf that I am the more qualified for this tark, as many have written on thefe phenomena and formed conjectures without having ever feen one inftarice, while I have been an eye witnefs of fome of the lateft. In a quarry not far from Caffel, between that city and the palace of Freyenhagen, I found three toads together in a pretty large block of free-ftone *. I remember, alfo, that, when a boy, our houfe at Caffel being under repair, and the old plafter pulled down, feveral toads were found between it and the ftone wall + .

At a period like the prefent, when fo many things are made the fubject of experiment, when every one endeavours to tread in the footfteps of a Bacon and a Newton, and, inftead of being contented with furveying Nature in her private receffes and carefully watching her progrefs, compels her as it were to labour and make known her fecrets, I am much aftonithed that the has not been put to the proof in this refpect long ago. Such experiments, without which all theory mult ever remain mere hypothefes, and can never amount to demonftration, would require little or no expence. Nothing would be neceffary but to make a deep hole in a ftone; to inclofe fome animal in it, fuch for example as a

* See Diff. Academicor. Inftitut. Bonon. (interp. Beccario) op. Benedic. XIV. P. M. de Sevor. Dei beatificat. I, iv. p. I. p. 328 ; and Beccarius in Commentar. Inftit. Bonon. tom. ii. p. 1. p. 323.

+ A full account of this circumftance, which I tranfmitted to $M_{a} \mathrm{Kaft}$ ner; way be found in the Golmzilcb. Anzeig. for 87960 
toad, and to prevent the air from penetrating to it: or eggs only might at firft be put into the ftone. It would, however, be attended with mot advantage if feveral experiments were made at the fame time, in order that the ftate of the animals might be examined at different periods. Such experiments, and careful obfervation of the nature and economy of thefe animals, could alone lead to any certain conclufion refpecting a circumftance fo abttrufe, which, at prefent, feems to furpafs the powers of our comprehenfion.

II. Obfervations on Snow and Rain; tbeir Influence on Vegetation, and tbeir Combination witb Oxygen. By J.H. Hassenfratz. From Journal de L'Ecole Polytechnique, $P . I V$. AlL thofe who inhabit parts of the earth expofed to
fnow, agree in confidering this meteor as one of the means employed by nature to give to plants more ftrength, and to make them expand with more vigour. Several even are perfuaded that winters which produce no fnow prefage a bad harveft and a feeble ftate of vegetation; and they afcribe its influence to the falts which they fay exift in that congealed water. Snow collected in large mafles, melted and evaporated in earthen veffels, having left no refiduum, has made this fuppofition be confidered as a mere chimera; and, in confequence of reafoning carried too far, fome have been induced to deny that fnow has any influence at all on vegetation.

In phenomena tranfmitted through fucceffive generations, we muft diftinguifh the refults of obfervation from the explanations fome have attempted to give of them. There are phenomena, indeed, the whole of which prefont themfelves to our fenfes in their full force, and which can leave no doubt in the mind of the leaft attentive obferver; but there are others which exhibit only a few traces that cannot be 